\title{
ENTOMOLOGICAL WORK IN MISSOURI
}

\section{By Leonard Haseman, Department of Entomology, University of Missouri}

All are familiar with the able work of Riley so well described and illustrated in his memorable Missouri Reports. This work was in large part practical and being in a new field was largely original. Even at the present time his illustrations and more technical descriptions are made use of. Unfortunately Missouri and the Middle West was not then able to fully appreciate the value of his work, and after nine years it was discontinued and by the farmer largely forgotten. Comparatively few of the older Missourians now remember him and his work, though entomologists will not soon forget him.

His work as state entomologist was under the supervision of the State Board of Agriculture with headquarters at St. Louis, Mo., and .after it was discontinued nothing was done in this state to control the insect pests until this department was established in 1895. At that time Stedman was appointed head of the department and an effort was made to investigate and improve entomological conditions in the state. Some headway was made, but the state is a large one and conditions were favorable for the work of insects and not always favorable for the work of control, so that from year to year conditions clearly grew worse. Funds were scarce in the early days, help difficult to get and such a thing as legal authority to control pests was unknown in the state. For the first few years after the work of this department began, a special effort was made to reach the farmer in a popular way, and while some little original work was done it was not of a technical nature. Agricultural conditions generally had materially improved since Riley began work here, so Stedman had a much better opportunity to reach the farmers and secure their coöperation. He began his work just after the San José scale was introduced into the state and while efforts were made to check it, they were met with lack of support and means, and consequently with failure. Had this department at that time done nothing more than stamp out this pest in the dozen or so orchards where it was then found, it would have far more than justified its existence. Since that time this pest has cost the state thousands of dollars, and will continue to cost it even more.

The writer has had charge of the entomological work here since 1910 and has found some of the original handicaps still existing. Lack of interest in insect control, and with it lack of support and assistance have always been a serious drawback in Missouri. This is being felt much less now than in former years though we need a dozen men in place of two to cope with the entomological conditions as they are now found in this state. 
Since taking charge of the work the writer has attempted to take up those particular pests or groups of pests which are of greatest importance and which have required special study. So far our attention has been directed mostly to the smaller projects which have not required continuous observations extending over a period of several years. Such projects have been out of question, but we are hoping to be able in the near future to undertake some of these larger lines of work. In recent years the orchard insects have been given most attention since there are so many of them and the fruit growers are by no means familiar with them and the methods of control. It should be said that the Missouri horticulturist is far behind the general farmer and stock man as regards up-to-date scientific methods. They have never gotten together for the improvement of horticultural conditions as the other men have. This is well shown by their failure to secure adequate legislation for the improvement of horticulture until the last legislature. It is hoped, however, that the interest they have shown in securing this state aid is a true sign that they are awakening to the horticultural needs and that they will give every assistance to the uplifting of this badly neglected industry in Missouri.

In connection with the carrying out of the horticultural inspection law provision is made for educational work, and if it is possible to reach the horticulturists at all we should do so through this work. A keen interest is being shown in this new work and the prospects, for accomplishing something worth while for Missouri horticulture, are bright. In attempting to get this new line of work in operation this year most of the experiment station projects had to be neglected so that we have made but little progress with them this year. It was thought, however, that the opportunities opened by this new work would warrant the temporary neglect of the investigation work.

The work of this department at present covers the regular instruction in the university, which includes three or four classes each semester and from one hundred and twenty-five to one hundred and fifty students; the experiment station projects with the various insect pests and groups of pests affecting agriculture and the nursery inspection work which has been taken up in real earnest this year. These various lines of work are handled by the writer and one assistant or rather they attempt to handle them. We feel that we are making some headway, though it seems slow at times, and we are often inclined to envy those in other states who are able to concentrate all their efforts on a certain project and when finished turn to something else.

One important but much neglected line of entomological work in this state is the improvement of conditions in bee-keeping. The state has done almost nothing to improve conditions and the growing 
demand for help is becoming very pronounced. This department has taken up the subject and is offering courses in bee-keeping and is undertaking investigations of problems of practical value to bee-keepers. The state has an apiary inspection law which is under the supervision of the State Board of Agriculture, but inadequate funds are provided and the work is therefore badly neglected. The experiment station is undertaking coöperative work with a view of lending some assistance to this industry.

In the future it shall be the aim of the writer to continue to expand the work of this department to meet the various new demands made on it, and with this increase of work it is hoped more help will be added so that we can do more and better work in Missouri. The appointment of an entomologist at the fruit experiment station in southern Missouri will help out, but there is still room for more entomologists. The field for practical as well as technical work here is unsurpassed, and it is a pleasure to labor under such conditions even with the small means at one's disposal. The state grows cotton in the south, corn and wheat in the north, and fruit everywhere; it has swamp, prairie and mountainous conditions with a varied fauna and flora scarcely touched by scientific students and as yet but slightly affected by the economic entomologist.

\section{AN INCIDENT IN THE SEARCH FOR FOREIGN GIPSY MOTH PARASITES}

By L. O. Howa RD

At a joint meeting of the Entomological Society of America and Section F of the A. A. A. S., held at Atlanta December 31, the writer read a paper on present conditions of the imported gipsy moth parasites in the course of which he laid aside his manuscript for a moment to tell an anecdote which he thought illustrated in a capital way, not only the difficulties to be met with in the field in a foreign country, but also the necessity not only for a thorough knowledge of the subject, but for imagination, fertility of resource, persistency, and energy on the part of the investigator, if the best results are to be reached.

After the meeting, and in fact during the discussion of the paper, several persons present urged me to write this story for publication in the JourNal. I am afraid that Mr. Fiske would not like me to do it, but he is out in Africa at present and I cannot well wait for his permission. I think that Doctor Fernald and the others who asked me to write the story for publication can make such good use of it in their teaching work that I shall overlook Fiske's possible objections, and so here is the story about as I told it. . It was apropos to a mention of the present condition in this country of Limnerium disparidis. 